\section{The effects of financial leverage and debt maturity on the investments of Brazilian electric sector companies}

\author{
Aline Kuroda ${ }^{1}$ \\ Herick Fernando Moralles ${ }^{1}$ \\ Andrei Aparecido de Albuquerque ${ }^{1}$ \\ ${ }^{1}$ Federal University of São Carlos, Department of \\ Production Engineering, São Carlos - Brazil
}

Received on

02/21/2018

Approved on

01/21/2019

Responsible editor:

Prof. Dr. Javier Montoya del

Corte

Evaluation process:

Double Blind Review

\begin{abstract}
Purpose - This research aimed to verify how companies of the electric energy segment choose levels of financial leverage and debt maturity in order to alleviate the underinvestment problem.
\end{abstract}

Design/methodology/approach - A multiple linear regression was carried out in a dynamic panel model to verify the relevance of these and other variables to the companies' investments.

Findings - The explanatory variable of investments carried out in the previous year was significant in the regressions, with a positive sign as expected. The financial leverage variable was significant and negative. The investments made by the companies are negatively related to indebtedness.

Originality/value - It was identified that the maturity of debts of companies with low growth opportunities shows a negative relationship with the level of investment. Thus, in the electricity sector, reducing debt maturity can be considered as a substitute for reducing indebtedness in controlling underinvestment. Due to the relevance of this sector to the economy and the need for constant investments in it, understanding its financing dynamics provides an important contribution either to researchers or to managers of this industry.

Keywords - Investment, Financial Leverage, Debt Maturity, Underinvestment.

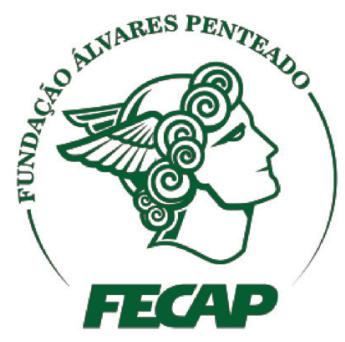

Review of Business Management

DOI: $10.7819 /$ rbgn.v21i3.4004 


\section{Introduction}

According to Montoya, Pasqual, Lopes, and Guilhoto (2013), it has been verified that the energy sector is one of the most relevant in the country, since it stimulates in a comprehensive and uniform way the economic growth of the various Brazilian sectors. In fact, studies such as that of Belke, Dobinik, and Dreger (2011) find a two-way causal relationship between energy consumption and economic growth through econometric causality tests. Thus, studies in this sector have become relevant because of its importance in the economy, but research that focuses on the relationship between the level of debt and investment specifically in companies in this segment is not so common.

According to Aivazian, Ge, and Qiu (2005), in incomplete markets, agency problems occur in the interactions between shareholders, creditors, and managers, which lead to situations of overinvestment or underinvestment. Such agency problems are more pronounced in emerging markets, such as Brazil, making it impossible to say whether investments are exclusively or completely carried out due to economic fundamentals. In this context, it can be affirmed that studying the relationship between the level of debt and investment and, more specifically, the possible underinvestment in Brazilian companies of the electric energy segment, is of vital importance to the economic growth of the country. In fact, a high level of debt of such companies may represent a strategic problem, since a reduction of investments, associated with the problem of underinvestment, could result in an insufficient supply of energy to meet the demand.

According to Montoya et al. (2013), in order to avoid energy production being a limiting factor of economic growth, investment goals must be clearly defined. Understanding the control mechanisms of underinvestment can help to achieve these goals and, consequently, ensure that the energy sector is not the bottleneck of Brazilian economic development.
According to Antunes and Procianoy (2003), financing is one of the fundamental financial decisions of companies. Financing can come from the company itself or from external sources through loans and financing. Some of these resources are intended for investments, hence the strong relationship between financial leverage and firm investment.

To evaluate the relationship between financial leverage and investment, authors such as Lang, Ofek, and Stulz (1996), Kinnunen (2006), Aivazian, Ge, and Qiu (2005), Firth, Lin, and Wong (2008), and Dang (2011) conducted studies in different regions, mostly developed economies, and identified a negative relationship between these two variables. A study in this area was developed in Brazil by Albuquerque and Matias (2013) and the observed results also indicate a negative relationship. According to Dang (2011), this relationship can be understood as the result of the underinvestment problem. According to Occhino and Pescatori (2014), underinvestment stems from situations in which the free cash flow generated by highly leveraged companies is primarily used to pay debts. Debt reduces shareholder participation in the benefits of a possible investment and causes companies to stop accepting projects with positive Net Present Value (NPV). Milstein and Tishler (2012) argue that underinvestment in electricity markets is a major concern for leaders.

In this context, analyses are warranted that consider the most relevant characteristics of the Brazilian scenario to understand how companies in the electricity sector control, or at least ease, the negative impact brought about by financial leverage on corporate investments. In addition, there is an expressive movement of foreign investors to join the Brazilian electricity sector, which is related to Cahen's arguments (2015), and further underpins the relevance of developing studies such as this one both in the field and in the explored sector.

The sectoral diversity of companies justifies the application of tests in a specific segment, since 
each sector can adopt distinct control mechanisms and, as Carvalho and Dias (2016) point out, the industry in which a company is set affects its performance. In addition, testing in a specific sector is suggested by Albuquerque and Matias (2013), thus allowing a contribution to be made in relation to this previous study developed in Brazil and that of Dang (2011), which did not develop sector-specific tests either. Thus, this study aims to determine how companies in the electric energy sector choose their level of financial leverage and debt maturity in order to alleviate the problem of underinvestment.

\section{En e r g y s e ctor a n d underinvestment}

Investments in the electricity sector are necessary to ensure competitiveness, supply, and quality of service. In this context, liberalization of the electricity market in many countries has created new challenges for the sector, with higher production efficiency and lower average electricity prices being the main justification for deregulation of the electricity market (Kinnunen, 2006; Luca \& Rambalducci, 2003).

Thus, long-term planning and asset management has been a priority concern for electricity distribution companies, given the volume of resources and the duration of their investment projects. This scenario intensifies the need for correct decisions in the planning process (Lassila, Viljainen, Tahvanainen, \& Partanen, 2007).

However, few studies have dealt with internal issues related to the decision-making regarding project financing in the electric sector, and studies have only been found that deal with related problems such as underinvestment in $\mathrm{R} \& \mathrm{D}$ in the US electric sector (Margolis \& Kammenb, 1999).

Alongside investment decisions is the choice of the companies' capital structure. The first decision regarding the structure consists in the choice of financing its activities with its own resources or with debt (Ribeiro, 2009). If the company opts for debt, it is necessary to define the maturity of the debt and its source of financing. The feasibility of this financing, considering the future applications of funds raised, will determine the degree of financial leverage. Brick and Liao (2017) report a positive relationship between debt maturity and cash retention, which also influences the financial leverage of companies.

Analyses of financial leverage in the Brazilian context must consider some existing inefficiencies that influence the financing decisions of companies. According to Ribeiro (2009), the level of capital market constraint, the high concentration of corporate control of companies, and the limited long-term sources of financing stand out. Added to these imperfections are the high interest rates that make financing costs significant, resulting in low levels of debt in Brazilian companies (Brito, Corrar, \& Batistella, 2007).

Financial leverage is affected by different factors analyzed by authors such as Perobelli and Famá (2002), Luca and Rambalducci (2003), and Nakamura, Jucá, and Bastos (2011). Among these factors, six have been presented by Finance Theory as being of greatest relevance: credit restrictions, debt maturity, use of collateral, profitability, cost of capital, and growth opportunities.

Myers (1977) argues that there are situations where creditors are entitled to a portion of cash benefits, which may be large enough to make a profitable project unable to offer a normal return to shareholders. In such situations, there is an incentive for shareholders to reject even projects with positive NPV. This is a situation that Myers (1977) calls the underinvestment problem. The problem of underinvestment occurs in companies with high growth opportunities, in situations characterized by a large number of profitable projects and high debt level. In these situations some managers discard new projects, with positive NPV, due to the allocation of marginal benefits to the payment of creditors, and not shareholders (Occhino \& Pescatori, 2014).

On the other hand, overinvestment, which is characteristic of companies with low growth 
opportunities, stems from the non-alignment of shareholder and manager incentives and leads to the use of free cash flows to finance unprofitable projects (Baptista, Matias, \& Valle, 2013). A lack of good investments in the maturity phase leads to projects being financed even if they do not have positive NPV and reduce shareholder wealth (Kayo \& Famá, 1997). This is because such investments will increase the size of the company and consequently increase the privileges of financial managers.

Although both problems have the same expected results for the interactions between financial leverage, growth opportunities, and investments, the implications of such interactions are distinct for companies with different growth expectations (Dang, 2011).

Both overinvestment and underinvestment are mentioned in Finance Theory as reasons for the negative relationship between financial leverage and investments and reflect situations in which the value of companies is affected.
Overinvestment impacts the value of companies through the acceptance of investment projects with negative NPV while underinvestment affects it through the rejection of projects with positive NPV (Morgado \& Pintado, 2003).

In the paper by Morgado and Pintado (2003), the existence of an optimal level of investment was identified through a quadratic relation between the value of companies and the investments made by them. On the other hand, Cookson (2017) argues that financial leverage is relevant both to the level of investment of companies and to the composition of the industry. Figure 1 shows that the value of a company will increase until the optimum investment point is reached, that is, up to all positive NPV projects are executed. Additional investments, which characterize overinvestment, are responsible for reducing its value, and levels below the optimal point are situations of underinvestment, where the company does not obtain the maximum value it could.

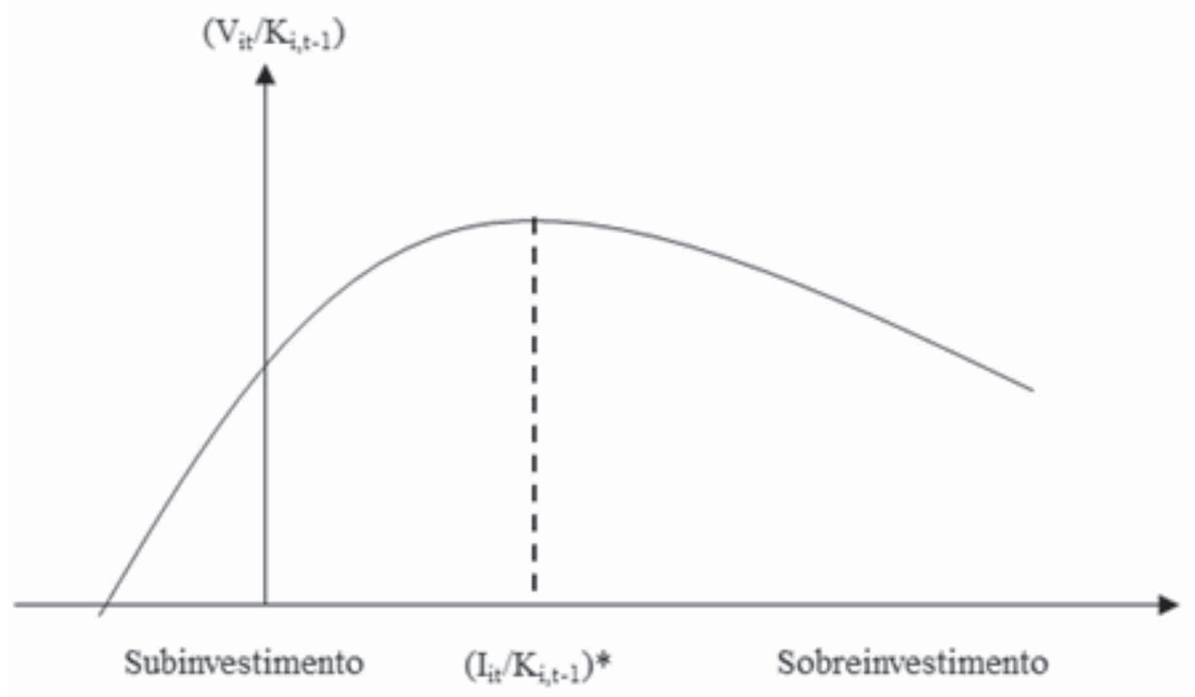

Figure 1 - Relationship between company value and investments: the best level Source: Morgado and Pintado (2003, p. 168) 
It can be seen, therefore, that companies with high growth opportunities should use control mechanisms to reduce the negative impact of financial leverage on investments. According to Rajan and Zingales (1995), these companies should use a greater proportion of equity, and consequently reduce their debt level. On the other hand, Barclay and Smith (1995) affirm that these companies tend to use more short-term debts to avoid discarding new investments due to insufficient resources.

It has also been suggested that companies with reduced growth opportunities should opt for the use of debts to avoid free cash flow being used to finance unprofitable investment projects (Stens, 1986; Stulz, 1990).

In situations of underinvestment, associated with highly indebted companies with high growth opportunities, managers opt to discard investment projects with positive NPV due to the allocation of marginal benefits to the payment of creditors and not shareholders (Occhino \& Pescatori, 2012). Consequently, such companies tend to maintain a lower level of investment when compared to less leveraged companies (Aivazian, Ge, \& Qiu, 2005).

In short, managers generally tend to choose investments that, in addition to having positive NPV, offer a residual remuneration to shareholders, thus generating benefits that exceed the amount of the debts acquired (La Rocca, M., Cariola, \& La Rocca, T., 2005).

Myers (1977) was the first author to note that for companies with high growth opportunities, financial leverage has negative effects on investment. Subsequently, authors such as McConnell and Servaes (1995) have affirmed that this relationship is reflected in the value of companies: the use of debts by companies with high growth opportunities is related to a reduction in the value of these companies.

In theory, it is expected that the negative effect created by debt on the level of investments will be mitigated through corrective actions, such as reducing debt maturity and reducing debt itself (Aivazian, Ge, \& Qiu, 2005). Short-term debts, according to Nakamura, Jucá, and Bastos (2011), allow their maturation to occur before growth opportunities materialize. Thus, they can ensure that the gains from new projects not only go to creditors.

However, short-term debt increases companies' liquidity risk; that is, they increase the risk that they will not be able to meet their short-term commitments (Dang, 2011). Thus, it can be concluded that the choice of debt maturity involves a trade-off between the liquidity risk inherent to short-term debt and the underinvestment problem, which is more intense when using long-term debt.

Johnson (2003) argues that companies whose growth opportunities are more important should choose to reduce the maturity of their debts while reducing financial leverage. This can be justified because by reducing their debt level, these companies ease the risk of liquidity arising from short-term debt. On the other hand, companies that already have liquidity problems should increase maturity, but still reduce financial leverage. In that case, the reduction of their debts will alleviate the problem of underinvestment intensified by long-term debt.

In the last few decades, authors have sought to investigate how companies alleviate the effect of underinvestment in some economies. Dang (2011), for example, looked at British companies from 1996 to 2003 and concluded that underinvestment is countered by reducing financial leverage and not by reducing the maturity of their debts. Thus, the analysis of British companies does not support the argument that reducing debt and reducing debt maturity are strategic substitutes for controlling underinvestment (Dang, 2011).

On the other hand, Johnson (2003) identified that American companies use short-term debt to mitigate the effect of underinvestment. This result suggests that these companies opt for increased liquidity risk by reducing the maturity of debt in order to reduce underinvestment 
and hence to cease losing available investment opportunities.

The Brazilian context most closely resembles the British one in terms of debt maturity. In both cases, corporate indebtedness stems mainly from the use of short-term debt, and therefore it is expected that Brazilian companies will not be able to make significant use of reducing the maturity of their debts in order to combat the problem of underinvestment, as American companies do, according to Johnson (2003).

In Brazil, long-term financing is difficult to obtain and is basically limited to BNDES, a federal public bank (Mota, Coelho, \& Holanda, 2014). Brazilian debt is therefore restricted to the use of short-term debt, whose maturity cannot be reduced as an option to combat underinvestment. Thus, according to this theoretical proposition, companies with high growth opportunities and that are highly leveraged tend to maintain a low level of investment when compared to less indebted companies. On the other hand, in order to maintain a high level of investment, these companies tend to opt for the use of equity.

Studies such as those of Dang (2011) and Albuquerque and Matias (2013), developed in the Brazilian market, are applied in all publiclytraded companies in the country, signaling the importance of conducting tests for specific sectors. Thus, analyses are warranted that consider the most relevant characteristics of the Brazilian scenario to understand how companies in the electric energy sector choose their level of financial leverage and debt maturity in order to alleviate the problem of underinvestment.

\section{Methods}

In order to estimate the model proposed below, we considered the Brazilian publiclytraded companies in the electric energy sector, in the quarters from 2003 to 2012, included in the Economática database, taking the necessary information extracted from their quarterly financial statements.

The publicly-traded companies in the Brazilian electricity sector selected were therefore those with publicly-available financial data. As in Dang (2011), companies that had no data in any of the periods analyzed were excluded. After applying these criteria, the sample consisted of 14 companies operating in the electricity generation, transmission, and distribution segments. Due to the small number of companies, it was not possible to restrict the study to only one of the aforementioned segments.

The 14 companies selected presented different profiles. Table 1 presents the turnover, shareholder composition (public, private, or mixed, that is, with a mixture of public and private shareholders), segment, and operating region of each of them, collected from BM\&F Bovespa. 
Table 1

Turnover, shareholder composition, segment, and operating region of the 14 companies analyzed.

\begin{tabular}{|c|c|c|c|c|}
\hline Company & $\begin{array}{c}2014 \text { Turnover } \\
\left(10^{6} \mathrm{R} \$\right)\end{array}$ & Composition & Segment & Area \\
\hline 1 - AES Elpa & $10,557.2$ & Mixed & $\begin{array}{c}\text { Generation, Transmission, and } \\
\text { Distribution }\end{array}$ & SP \& RS states \\
\hline 2 - AES Tiete & $3,205.0$ & Mixed & Generation & SP state \\
\hline 3-Ampla Energ & $6,139.9$ & Private & Distribution & RJ state \\
\hline 4-Ceee-gt & $2,849.0$ & Mixed & $\begin{array}{c}\text { Generation, Transmission, and } \\
\text { Distribution }\end{array}$ & RS state \\
\hline $5-$ Celesc & $6,246.2$ & Mixed & $\begin{array}{c}\text { Generation, Transmission, and } \\
\text { Distribution }\end{array}$ & SC state \\
\hline 6-Celpa & $3,987.1$ & Private & Distribution & PA state \\
\hline 7 - Cemar & $2,484.2$ & Private & Distribution & MA state \\
\hline 8 - Coelba & $5,733.0$ & Private & Distribution & BA state \\
\hline 9 - Copel PNB & $13,900.0$ & Mixed & $\begin{array}{c}\text { Generation, Transmission, and } \\
\text { Distribution }\end{array}$ & PR state \\
\hline 10 - Duke Energy & $1,222.9$ & Mixed & Generation & SP \& PR states \\
\hline 11 - Eletropaulo & $10,557.2$ & Mixed & Distribution & SP state \\
\hline 12 - Energisa MT & $2,637.8$ & Mixed & Generation and Distribution & MT state \\
\hline 13 - Light S/A & 661.88 & Private & Distribution & RJ state \\
\hline 14 - Tractabel & $6,472.5$ & Private & Generation & $\begin{array}{l}\text { RS, SC, PR, SP, MG, MS, MT, } \\
\text { GO, TO, MA, PI, \& CE states }\end{array}$ \\
\hline
\end{tabular}

It can be noted that the selected sample is composed of companies of different sizes and geographical regions. With regard to capital structure, it is observed that although all the companies are private, some of them have a mixed shareholder composition, that is, also have public shareholding.

The participation of public companies can interfere in the decision-making process, through differentiated policies. By not presenting purely public companies, this impact is minimized and the results can be analyzed together.

In this study, a simplified method similar to that of Dang (2011) is proposed, which aims to verify the control methods used by Brazilian companies in the electric energy sector. This allowed for comparisons between the Brazilian and British scenarios, as well as between the energy sector in Brazil and British companies in general.

After the data collection, a multiple linear regression model was developed in a dynamic panel model. The use of this analysis technique in this model is essential, since the investments of a company depend on different variables, including financial leverage, cash flow, and growth, as suggested by Aivazian, Ge, and Qiu (2005), Dang (2011), and Albuquerque and Matias (2013), among others. So, the dependent variable in this study, the level of investments, necessarily presents a linear relationship with the $\varphi$ coefficients, even if its relationship with the other variables is not.

The use of panel data is also justified due to its advantages when compared to models with cross-sectional data or time series, including a more informative data supply, greater variability, lower collinearity, and greater efficiency.

An equation was employed to define the level of investment carried out by companies. This equation, applied by Dang (2011), can be written according to Equation (1) 


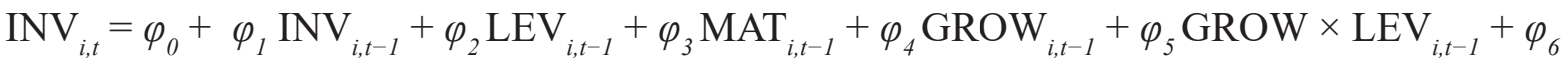
$\mathrm{GROW} \times \mathrm{MAT}_{i, t-1}+\varphi_{7} \mathrm{CF}_{i, t-1}+\varphi_{i}+w_{i, t}$,

Where:

$\mathrm{INV}_{i, t}=$ investment by company $\mathrm{i}$ in year $\mathrm{t}$;

$\mathrm{LEV}_{i, t-1}=$ financial leverage of company $\mathrm{i}$ in year $\mathrm{t}-1$;

$\mathrm{MAT}_{i, t-1}=$ maturity of company i's debts in year $\mathrm{t}-1$;

$\mathrm{GROW}_{i, t-1}=$ growth opportunities of company i in year $\mathrm{t}-1$;

$\mathrm{CF}_{i, t-1}=$ cash flow of company $\mathrm{i}$ in year $\mathrm{t}-1$;

$\varphi_{i}=$ term representing the unobservable companies and/or specific effect of the industry;

$\mathrm{w}_{i, t}=$ term that represents the error associated with company $\mathrm{i}$ in year $\mathrm{t}$ so that $\mathrm{w}_{i, t} \sim \operatorname{iid}\left(0, \mathbb{\nabla}^{2}\right)$.

The calculation of these variables, detailed in Table 2, was a result of a mixture of those used by Dang (2011) and Albuquerque (2013).

Table 2

\section{Variables used in the model}

\begin{tabular}{ll}
\hline Variable & Description \\
\hline $\mathrm{INV}_{\mathrm{i}, \mathrm{t}}$ & $\begin{array}{l}\text { Subtraction of the value of operating liabilities - not onerous - from the total value of assets, divided by fixed assets } \\
\text { (fixed assets) of the previous period (Albuquerque, 2013) }\end{array}$ \\
LEV $_{\mathrm{i}, \mathrm{t}-1}$ & $\begin{array}{l}\text { Ratio between total debt (sum of loans, financing, and long-term and short-term debentures) and total assets } \\
\text { (Albuquerque, 2013) }\end{array}$ \\
$\mathrm{MAT}_{\mathrm{i}, \mathrm{t}-1}$ & $\begin{array}{l}\text { Ratio between long-term debt (longer than one year) and total debt (loans, financing, and short-term and long-term } \\
\text { debentures) (Dang, 2011) }\end{array}$ \\
$\mathrm{GROW}_{\mathrm{i}, \mathrm{t}-1}$ & $\begin{array}{l}\text { Measured by Tobin's Q (Q): sum of the market value of the shares multiplied by the number of shares and the book } \\
\text { value of the debts, divided by the book value of total assets (Albuquerque, 2013, Dang, 2011) }\end{array}$ \\
$\mathrm{CF}_{\mathrm{i}, \mathrm{t}-1}$ & Addition of net income to depreciation, divided by fixed assets of the previous period (Albuquerque, 2013)
\end{tabular}

According to Equation (1), the expected level of investment for company $\mathrm{i}$ in year $\mathrm{t}$ is defined by an intercept, the lagged investments, financial leverage, debt maturity, growth opportunities, and cash flow associated with the previous year ( $t-1)$ and the impact that the opportunities have on both maturity and leverage.

According to Dang (2011), some variables described above present, according to the theory, an expected relationship with a company's investment level. It is assumed that the growth opportunities of the previous period are positively related to investments. This is because a higher Tobin's $Q$, coupled with an increase in the market value of a company against its book value, generates higher expectations of future profits, and these profits allow the company to make more investments. Dang (2011) states that the coefficient of the cash flow variable tends to be significantly positive for companies with some form of financial constraint. Studies such as those by Aivazian, Ge, and Qiu (2005) and Albuquerque and Matias (2003) found a significant positive relationship between cash flow and investment, demonstrating the relevance of considering it in the model tested here.

The financial leverage and maturity of the debts of the previous period, in turn, should have a negative relationship with the level of investments, since a higher level of debt or greater 
maturity tends to reduce ex post investments (Dang, 2011). Finally, Dang (2011) also states that it is expected that both coefficients of the terms of interaction with growth opportunities $\varphi 4$ and $\varphi 5$ are negative.

In order to avoid specification bias, other lesser-known exogenous control variables that may influence the level of investment of companies were also considered in the model, namely the Brazilian Population (BP) and the Brazilian Gross Domestic Product (GDP). All the information was collected from Ipeadata, whose data come from the Brazilian Institute of Geography and Statistics (IBGE).

\section{Result analysis}

Through the descriptive statistics shown in Table 3, it is possible to confirm the high variability of the data on the Brazilian companies, as already observed in other studies, for example in the one by Albuquerque and Matias (2013).

Table 3

\section{Descriptive statistics for model variables}

\begin{tabular}{lcccccc}
\hline Variable & $\mathbf{N}$ & mean & median & min & max & sd \\
\hline Investment $(\mathrm{R} \$)$ & 560 & 15.855 & 15.682 & 14.102 & 17.422 & 0.659 \\
Cash Flow (R\$) & 560 & 6.384 & 6.376 & 0.000 & 6.908 & 0.365 \\
Tobin's Q & 560 & 1.04 & 0.73 & 0.15 & 17.66 & 1.05 \\
Maturity & 560 & 0.77 & 0.82 & 0.05 & 1.00 & 0.18 \\
Financial Leverage & 560 & 0.34 & 0.32 & 0.01 & 1.03 & 0.17 \\
BR Population & 560 & $185,000,000$ & $185,000,000$ & $180,000,000$ & $190,000,000$ & $5,004,470$ \\
Brazilian GDP (R\$ x1000) & 560 & 18,426 & 146 & 112 & 41,3486 & 69,588 \\
\hline
\end{tabular}

In addition to the aforementioned high variability of the data, it is worth noting the observation of companies with zero cash flow, which indicates companies with possible financial restrictions and, consequently, an atypical positioning in relation to possible investments.

It is also observed that companies in this sector have a high degree of long-term debt, as can be noted from the average maturity variable (0.77). This observation reaffirms the relevance of this study for a specific sector, since this average surpasses the one observed for all publicly-traded companies in Brazil of approximately 0.50, as reported by Albuquerque (2013). Therefore, companies in the Brazilian electricity sector are able to use more intensive long-term financing.

Finally, the average financial leverage of this sector is lower than that observed by Albuquerque (2013), which was 0.57. Evaluating this together with the variable maturity, it can be inferred that the companies of the electric sector use less short-term debt than the average of Brazilian publicly-traded companies.

In the dynamic-panel model with variables in natural logarithms presented in equation (1), by construction, the lagged dependent variable (INVi, t-1) is correlated with the unobserved individual effect, so that it is possible to estimate the model based on the equations of moments constructed based on higher lags of INVi and the first differences of the residuals as proposed by Arellano and Bond (1991).

However, if the autoregressive process is very persistent, that is, if autoregressive parameters are high, or if the ratio of the panel-level variance to the idiosyncratic error variation is very high, according to Blundell and Bond (1998) such higher lags are weak instruments, making the estimator of Arellano and Bond (1991) perform poorly, and they therefore propose an alternative estimator that makes use of additional conditional moments. 
Thus, considering that the sample employed in this investigation makes use of quarterly data, assuming high persistence in the auto regression process, it was decided to perform the estimation of the model of equation (1) through the system (SYS-GMM) developed by Blundell and Bond (1998) using Stata SE 13 software.

Specifically, the results presented in Tables 4 and 5 show 4 different ways of performing the
Blundell and Bond (1998) estimation, and they all make a robust estimation of the heteroscedasticity for the variance-covariance matrix of the estimator.

Form (I) uses a two-stage estimator rather than one stage for the Blundell and Bond (1998) technique, while form (II) adds a second lag to the investment variable. Finally, forms (III) and (IV) extend the number of lags of the dependent variables used as instruments respectively by 4 and 8 quarters.

Table 4

Estimated parameters for the independent variables of Equation 1

\begin{tabular}{|c|c|c|c|c|}
\hline \multirow{2}{*}{ VARIABLES } & (I) & (II) & (III) & (IV) \\
\hline & SYS -GMM & SYS -GMM & SYS -GMM (4 lags) & SYS -GMM (8 lags) \\
\hline \multirow[t]{2}{*}{ INVi,t-1 } & 0.356 & 0.429 & $0.947^{* * *}$ & $0.937^{* * *}$ \\
\hline & $(3.575)$ & $(4.278)$ & $(0.0244)$ & $(0.0260)$ \\
\hline \multirow[t]{2}{*}{ INVi,t-2 } & & 0.372 & & \\
\hline & & $(12.95)$ & & \\
\hline \multirow[t]{2}{*}{$\mathrm{CFi}, \mathrm{t}-1$} & -0.00727 & -0.0285 & $0.0390^{* * *}$ & $0.0359^{* * *}$ \\
\hline & $(1.364)$ & $(1.608)$ & $(0.00711)$ & $(0.00527)$ \\
\hline \multirow[t]{2}{*}{ MATi,t-1 } & 0.0457 & 0.0456 & $-0.0258^{* *}$ & -0.0175 \\
\hline & $(2.098)$ & (2.068) & $(0.0121)$ & $(0.0125)$ \\
\hline \multirow[t]{2}{*}{ LEVi,t-1 } & 0.257 & 0.493 & $-0.0261^{* * *}$ & $-0.0205^{* * *}$ \\
\hline & $(9.612)$ & $(4.178)$ & $(0.00650)$ & $(0.00479)$ \\
\hline \multirow[t]{2}{*}{ GROWi,t-1 } & -0.00558 & -0.0170 & 0.0190 & $0.0257^{* *}$ \\
\hline & $(5.762)$ & $(3.096)$ & $(0.0127)$ & $(0.0124)$ \\
\hline \multirow[t]{2}{*}{$\begin{array}{l}\text { GROW } \times \\
\text { LEVi,t-1 }\end{array}$} & 0.0374 & 0.0143 & $-0.0113^{* * *}$ & $-0.0109^{* * *}$ \\
\hline & $(0.407)$ & $(1.374)$ & $(0.00310)$ & $(0.00252)$ \\
\hline \multirow[t]{2}{*}{$\begin{array}{l}\text { GROW } \times \\
\text { MATi,t-1 }\end{array}$} & -0.333 & -0.229 & $-0.0342^{* *}$ & -0.0214 \\
\hline & $(3.857)$ & $(3.676)$ & $(0.0160)$ & $(0.0158)$ \\
\hline \multirow[t]{2}{*}{ POP } & 0.966 & 0.0496 & 0.156 & 0.122 \\
\hline & $(37.87)$ & $(62.12)$ & $(0.136)$ & $(0.158)$ \\
\hline \multirow[t]{2}{*}{ GDP } & -0.651 & -0.527 & 0.00778 & 0.0109 \\
\hline & $(3.850)$ & $(10.24)$ & $(0.0106)$ & $(0.0101)$ \\
\hline \multirow[t]{2}{*}{ Constant } & -5.504 & 3.360 & -2.323 & -1.537 \\
\hline & $(761.8)$ & $(1,063)$ & $(2.594)$ & $(2.949)$ \\
\hline
\end{tabular}

Number of observations: 560 Standard errors in parentheses

${ }^{* * *} \mathrm{p}<0.01,{ }^{* *} \mathrm{p}<0.05,^{*} \mathrm{p}<0.1$

Notes: the variables are expressed by their respective acronyms: investment (INV); cash flow (CF); maturity (MAT); financial leverage (LEV); Tobin's Q - Growth (GROW); Brazilian population (POP); Brazilian Gross Domestic Product (GDP). The results were obtained by applying the Stata software. 
The GMM estimators employed in Tables 4 and 5 are valid only if there is no serial correlation in the residuals, thus requiring the Arellano-Bond test for autocorrelation in the first difference in the residuals.

Considering that the first difference of white noise is necessarily autocorrelated, the only relevant statistic is the second-order one, which presented a p-value of 0.1472 , so that it was not possible to reject the null hypothesis that postulates the absence of autocorrelation, thus validating the estimator.

The Sargan test rejected the null hypothesis of valid instruments (Prob> chi $2=0.000$ ), indicating the possibility of the instruments being correlated with the residual. However, some studies such as the one by O'Mahony and Vecchi (2009) have rejected the validity of the Sargan test based on its tendency to overly reject the null hypothesis in the equations specified in the first differences, as pointed out by Blundell and Bond (1998).

From Table 4, it is possible to observe that the best results were obtained in the estimates of regressions (III) (4 lags) and (IV) (8 lags), so the comments focus on them. These results allow us to identify that the explanatory variable INVi, t-1, that is, the investment made in the previous year, was significant in the regressions, with a positive sign as expected. According to Dang (2011), this is due to the accelerating influence that past investment has on current investment. Thus, it can be observed that the investment made one year (4 quarters) or two years (8 quarters) earlier is relevant to the definition of current investment.

The GROWi, $t-1$ variable remained statistically insignificant in most of the estimates, with the exception of estimate 4. In this one, the growth opportunities have, as expected, a positive relationship with investment. This is due to the fact that high growth companies tend to carry out a larger volume of investments (Dang, 2011). However, this relationship was statistically significant only for the 8-quarter lag.

On the other hand, the LEVi, t-1 variable was significant and had the expected negative sign.
We conclude that, as verified by Albuquerque and Matias (2013), the investments made by companies are negatively related to their debt level. This finding is in line with the overinvestment and underinvestment theories, respectively associated with companies with low and high growth opportunities (McConnell \& Servaes, 1995).

The MATi, $\mathrm{t}-1$ variable was only significant in estimate III (4-quarter lag). However, it had a negative sign as expected. Following the logic of Dang (2011), both leverage and maturity have a negative relationship, that is, the higher the debt maturity, the lower the level of investment. Albuquerque (2013) reports a positive relationship between these variables in his results, which demonstrates a different behavior of companies in the electric sector compared to all Brazilian companies.

The literature points to the reduction of debt maturity as an alternative to minimize the negative impact between financial leverage and investments resulting from underinvestment. According to Stohs and Mauer (1996), companies with high growth opportunities use reduced maturity because short-term debt matures prior to investment options, preventing new projects with positive NPV from being discarded due to insufficient cash flows.

The identification of a positive relationship between maturity and investment can be associated with the Brazilian context. Long-term financial resources, whose source is basically limited to BNDES, are restricted to large companies that are consolidated in the credit market (Mota, Coelho, \& Holanda, 2014). Thus, the predominance of short-term debt is not due to a control mechanism of underinvestment, but rather to restricted access to long-term credit.

Associated with a lower cost of capital, long-term debt reduces the expected minimum rate of return, since an investment is only feasible when the rate of return is greater than the cost of capital involved (Schroeder, Schroeder, Costa, \& Shinoda, 2005). 
Therefore, holders of long-term financing in the Brazilian context tend to have a higher level of investment, thus justifying the positive relationship between maturity and investment.

The GROW $\times$ LEVi, $t-1$ and GROW $\times$ MATi, $\mathrm{t}-1$ variables composed by the interaction with growth opportunities were also significant, with only one exception in the IV estimate, in which GROW $\times$ MATi, t-1 was not significant. The sign of both interactions is consistent with the identified relationship between investment and leverage (negative) and investment and maturity (negative). However, since the GROWi, $\mathrm{t}-1$ variable was only significant in the 8 -period lag model, the relationship between growth and investment opportunities does not provide the empirical support needed to prove the impact of this interaction.

The CFi, $t-1$ variable was significant and had the expected positive sign. It should be mentioned that although statistically insignificant, the results in estimates I and II indicate a negative relationship between cash flow and investment. These results may be related to the arguments regarding working capital management listed by Aktas, Croci, and Petmezas (2015), who suggest that if there is adequate management of working capital, the company can use its resources for higher value investments.

The GDP and Brazilian population variables did not present statistical significance in any of the estimates, and were therefore not relevant in defining investment according to the proposed model.

The implications noted from the abovementioned tests are consistent with both underinvestment and overinvestment theory, since both result in similar relationships between investment, financial leverage, and debt maturity. However, these theories have different implications for companies with different growth prospects.

The theory of underinvestment is characteristic of companies with high growth opportunities, while overinvestment occurs mostly in companies with low opportunities (Dang, 2011).

Therefore, to test the robustness of the underinvestment hypothesis, new estimates were made in the Stata software by including two new Dummy $\times$ LEVi, t-1 and Dummy $\times$ MATi, $t-1$ variables, both multiplied by a dummy variable of 1 for companies whose growth opportunities are above average, and 0 otherwise.

These tests make it possible to identify whether the relationships between investment, leverage, and maturity apply to companies with high and/or low growth opportunities. In this way, one can infer which theory (under or overinvestment) is of greatest relevance in the relationships identified. Table 5 presents the results of the estimates with the insertion of the dummy variable. 
Table 5

Estimated parameters for the independent variables of Equation 1 using dummy variables

\begin{tabular}{|c|c|c|c|c|}
\hline & (I) & (II) & (III) & (IV) \\
\hline VARIABLES & SYS -GMM & SYS -GMM & SYS -GMM (4 lags) & SYS -GMM (8 lags) \\
\hline \multirow[t]{2}{*}{ INVi,t-1 } & 0.136 & 0.303 & $0.950^{* * *}$ & $0.939^{* * *}$ \\
\hline & $(6.541)$ & $(14.16)$ & $(0.0217)$ & $(0.0217)$ \\
\hline \multirow[t]{2}{*}{ INVi,t-2 } & & 0.500 & & \\
\hline & & $(21.83)$ & & \\
\hline \multirow[t]{2}{*}{$\mathrm{CFi}, \mathrm{t}-1$} & -0.0972 & -0.0804 & $0.0394^{* * *}$ & $0.0368^{* * *}$ \\
\hline & $(1.114)$ & $(0.964)$ & $(0.00753)$ & $(0.00611)$ \\
\hline \multirow[t]{2}{*}{ MATi,t-1 } & -0.00670 & 0.0756 & $-0.0251^{*}$ & -0.0149 \\
\hline & $(3.874)$ & $(1.981)$ & $(0.0134)$ & $(0.0122)$ \\
\hline \multirow[t]{2}{*}{ LEVi,t-1 } & 0.266 & 0.218 & $-0.0212^{* * *}$ & $-0.0113^{* *}$ \\
\hline & $(7.963)$ & $(22.06)$ & $(0.00610)$ & $(0.00576)$ \\
\hline \multirow[t]{2}{*}{ GROWi,t-1 } & -0.123 & 0.134 & 0.0212 & $0.0266^{* *}$ \\
\hline & $(3.924)$ & $(4.672)$ & $(0.0134)$ & $(0.0125)$ \\
\hline \multirow[t]{2}{*}{ GROW $\times$ LEVi,t-1 } & -0.0410 & -0.00185 & $-0.0108^{* * *}$ & $-0.0105^{* * *}$ \\
\hline & $(0.638)$ & $(1.262)$ & $(0.00305)$ & $(0.00250)$ \\
\hline \multirow[t]{2}{*}{ GROW $\times$ MATi,t-1 } & 0.223 & 0.323 & -0.0273 & -0.0122 \\
\hline & $(3.069)$ & $(9.067)$ & $(0.0186)$ & $(0.0167)$ \\
\hline \multirow[t]{2}{*}{ Dummy $\times$ LEVi,t-1 } & 0.214 & 0.631 & 0.0245 & 0.0179 \\
\hline & $(8.350)$ & $(19.84)$ & $(0.0268)$ & $(0.0292)$ \\
\hline \multirow[t]{2}{*}{ Dummy $\times$ MATi,t-1 } & 0.00406 & -0.318 & 0.0117 & 0.0416 \\
\hline & $(22.47)$ & $(24.00)$ & $(0.0442)$ & $(0.0515)$ \\
\hline \multirow[t]{2}{*}{ POP } & 0.817 & 0.366 & 0.150 & 0.113 \\
\hline & (4.133) & (28.01) & $(0.152)$ & $(0.171)$ \\
\hline \multirow[t]{2}{*}{ GDP } & -0.426 & -0.738 & 0.00228 & 0.00456 \\
\hline & $(2.843)$ & (9.091) & $(0.0102)$ & $(0.00893)$ \\
\hline \multirow[t]{2}{*}{ Constant } & 0 & 0 & -2.234 & -1.400 \\
\hline & $(0)$ & $(0)$ & $(2.899)$ & $(3.188)$ \\
\hline
\end{tabular}

Number of observations: 560 Standard errors in parentheses

*** $\mathrm{p}<0.01,{ }^{* *} \mathrm{p}<0.05,{ }^{*} \mathrm{p}<0.1$

Notes: the variables are expressed by their respective acronyms: investment (INV); cash flow (CF); maturity (MAT); financial leverage (LEV); Tobin's Q - Growth (GROW); Brazilian population (POP); Brazilian Gross Domestic Product (GDP). The results were obtained by applying the Stata software.

The introduction of the new variables did not significantly alter most of the results. Prior period investments, cash flow, maturity, leverage, and growth opportunities maintained the previous sign and significance. The only notable change was that the GROW $\times$ MATi, $t-1$ variable became insignificant also in estimate III. That is, the introduction of the dummy variables did not have a major impact on the relationship with the level of investment, and these variables were not significant in all the tests.

It is concluded that the maturity of the debts has a negative impact only on the level of investments in companies with low growth opportunities. This indicates that for these companies, the higher the ratio of long-term debt to total debt, the lower the degree of investment. However, this relationship is low in terms of the 
estimator (0.0251) and only valid in the 4-period lag; however, it is consistent with the results of Dang (2011) and Aivazian, Ge, and Qiu (2005).

This finding differs from that observed in the Brazilian context, where the supply of long-term funds is scarce and concentrated in a few development institutions, especially BNDES (Mota et al., 2014). Small companies with low growth opportunities are restricted and consequently do not have access to long-term funding. They only use external financing when credit constraints are minimized by building a reputation in the market (Devos, Dhillonb, Jagannathanb, \& Krishnamurthyc, 2012).

Therefore, as these companies consolidate and access to long-term debt becomes possible, their level of investment tends to be higher. As verified by Albuquerque (2013), this mechanism suggests the existence of a positive relationship between investments and the maturity of the debts of companies with low growth opportunities. This is consistent with Cookson's (2017) arguments regarding the role of debt financing in company expansions.

\section{Final considerations}

The aim of this study was to investigate how companies in the electric energy sector choose their level of financial leverage and maturity of debts in order to alleviate the problem of underinvestment in companies with high growth opportunities. Underinvestment may explain the negative relationship identified by Albuquerque and Matias (2013) between financial leverage and the level of investments.

To mitigate this relationship, the literature points to two control mechanisms of underinvestment: reducing the level of debt and reducing debt maturity. As well as reducing the level of debt, the use of short-term debt prevents viable projects from being discarded due to insufficient cash flows because they would mature prior to the investment options.

It was observed in this study that independently of the growth prospects, the companies present a negative relationship between investment and debt levels. It is concluded that this relationship is not explained by underinvestment alone, a characteristic of companies with high growth opportunities. It may also be associated with overinvestment, as pointed out by Dang (2011), as a way of using debts to limit the decision-making power of managers. This limitation is based on the fact that free cash flow must be used primarily for the payment of the principal and interest arising from past debts.

It was also verified that the maturity of the debts of companies with low growth opportunities presents a negative relationship with the level of investment. It can be concluded that in the electric energy sector, reducing maturity can be considered a substitute for reducing the level of debt in the control of the underinvestment, but only when this occurs in advance of one year (4 quarters) from the investment. This finding converges with the results of Dang (2011) and Aivazian, Ge, and Qiu (2005), indicating that companies in the Brazilian electric sector are subject to a relationship between maturity and investment in a similar way to that observed in companies of the United Kingdom and Canada in previous studies.

On the other hand, the results of this study indicate that long-term debt does not play a positive role in terms of investment in companies in the Brazilian electricity sector. This finding is supported by the negative relationship observed between financial leverage and investments and between debt maturity and investments identified in the estimates carried out.

This study contributes to the literature by addressing another aspect of the association between the form of financing (capital structure) and the investments of companies, the latter being responsible for the growth and continuity of organizations. Moreover, the application of the study in the electric power sector boosts the importance of this research since, according to Montoya et al. (2013), the energy sector is the main key sector in Brazil and stimulates the 
economic growth of others. The development provided by investments in the energy sector has repercussions on all primary, secondary, and tertiary activities, and may be a limiting factor to progress.

This study may also motivate further research in this area of study. Due to their importance, other studies still have to be carried out in order to understand the dynamics of financial decisions and their implications in the level of investments. Future studies could focus on the impact of an increase in the supply of long-term funding, which is scarce in the Brazilian economy, on company investment; they could compare the results obtained in this study with those in other sectors; and they could search for other relevant elements that explain the relationship between financing decisions and investment.

Similar research has been carried out in other countries by different authors. The methods applied and the estimates made in this study have limitations. Other tests, such as the simultaneous equations used by Dang (2011), could be employed and the results could be compared with those presented in this study.

Another limitation may be associated with the small number of companies analyzed. However, it is noteworthy that this number is significant for the sector and incorporates its main components. On the other hand, the larger the sample, the better the results obtained through the estimations performed, and, therefore, the application of the model in other sectors that provide larger samples could present more accurate results.

\section{References}

Aivazian, V. A., Ge, Y., \& Qiu, J. (2005). Debt maturity structure and firm investment. Financial Management, 34(3), 107-119. Retrieved from: http://www.jstor.org/stable/3666400

Aktas, N., Croci, E., \& Petmezas, D. (2015). Is working capital management value-enhancing?
Evidence from firm performance and investments. Journal of Corporate Finance, 30, 98-113. http:// dx.doi.org/10.1016/j.jcorpfin.2014.12.008

Albuquerque, A. A. (2013). Alavancagem financeira e investimento: um estudo nas empresas brasileiras não financeiras de capital aberto. $99 \mathrm{f}$. Thesis (Doctoral) at the Faculdade de Economia, Administração e Contabilidade de Ribeirão Preto, Universidade de São Paulo, Ribeirão Preto.

Albuquerque, A. A., \& Matias, A. B. (2013). Identificando a relação entre alavancagem financeira e investimento nas empresas brasileiras não financeiras de capital aberto. Contextus - Revista Contemporânea de Economia e Gestão, 11(2), 76104. doi:10.19094/contextus.v11i2.446

Antunes, M. A., \& Procianoy, J. L. (2003). Os efeitos das decisōes de investimento das empresas sobre os preços de suas ações no mercado de capitais. Revista de Administração, USP, São Paulo, 38(1), 5-14. Retrieved from: http://www.spell. org.br/documentos/ver/16712/os-efeitos-dasdecisoes-de-investimentos-das-empresas-sobreos-precos-de-suas-acoes-no-mercado-de-capitais

Arellano, M., \& Bond, S. (1991). Some tests of specification for Panel Data: Monte Carlo evidence and an application to employment equations. The Review of Economic Studies, 58(2), 277-297. doi: 10.2307/2297968

Assaf, A., Neto, \& Lima, F. G. (2011). Curso de administração financeira (2nd ed.). São Paulo: Atlas.

Baptista, C., Matias, F., \& Valle, P. (2013). Fatores moderadores da dependência do investimento relativamente à liquidez interna. Tourism \& Management Studies, 9(2), 71-77. Retrieved from: http://www.redalyc.org/articulo. oa?id=388743879011

Barclay, M. J., \& Smith, C. W. Junior (1995). The maturity structure of corporate debt. The Journal of Finance, 50(2), 609-631. doi:10.2307/2329421 
Belke, A., Dobinik, F., \& Dreger, F. (2011). Energy consumption and economic growth: New insights into the cointegration relationship. Energy Economics, 33(5), 782-789. doi:10.1016/j. eneco.2011.02.005.

Blundell, R., \& Bond, S. (1998). Initial conditions and moment restrictions in dynamic panel data models. Journal of Econometrics, 87(1), 115-143. doi: https://doi.org/10.1016/S03044076(98)00009-8

Brick, I. E., \& Liao, R. C. (2017). The joint determinants of cash holdings and debt maturity: the case for financial constraints. Review of Quantitative Finance and Accounting, 48(3), 597-641.

Brito, G. A. S., Corrar, L. J., \& Batistella, F. D. (2007). Fatores determinantes da estrutura de capital das maiores empresas que atuam no Brasil. Revista Contabilidade e Finanças, USP, São Paulo (43), 9-19. doi: 10.1590/S151970772007000100002

Cahen, F. R. (2015). Internationalization of state-owned enterprises through foreign direct investment. RAE-Revista de Administração de Empresas, São Paulo, 55(6), 645-659. doi: http:// dx.doi.org/10.1590/S0034-759020150603

Cameron, A. C. T., \& Pravin, K. (2009). Microeconometrics Using Stata. Texas: Stata Press.

Carvalho, J. P., \& Dias, A. T. (2016). Influências não lineares da indústria no desempenho $\mathrm{da}$ firma. RAE-Revista de Administração de Empresas, São Paulo, 56(5), 503-517. doi: http://dx.doi. org/10.1590/S0034-759020160505

Cookson, J. A. (2017). Leverage and strategic preemption: Lessons from entry plans and incumbent investments. Journal of Financial Economics, 123(2), 292-312. doi: https://doi. org/10.1016/j.jfineco.2016.11.005

Dang, V. A. (2011). Leverage, debt maturity and firm investment: an empirical analysis.
Journal of Business Finance \& Accounting, Hoboken, 38(1-2), 225-258. doi: 10.1111/j.14685957.2010.02215.x

Devos, E., Dhillonb, U., Jagannathanb, M., \& Krishnamurthyc, S. (2012). Why are firms unlevered? Journal of Corporate Finance, Amsterdam, 18(3), 664-682. doi: 10.1016/j. jcorpfin.2012.03.003

Firth, M., Lin, C., \& Wong, S. M. L. (2008). Leverage and investment under a state-owned bank lending environment: Evidence from China. Journal of Corporate Finance, 14(5), 624-653. doi: 10.1016/j.jcorpfin.2008.08.002

Gujarati, D. N., \& Porter, D. C. (2011). Econometria Básica. Porto Alegre: AMGH.

Jensen, M. C. (1986). Agency costs of free cash flow, corporate finance, and takeovers. The American Economic Review, 76(2), 323-329. Retrieved from: http://u.osu.edu/young.53/ files/2016/12/Jensen-1986-free-cash-flows14 lmoes.pdf

Johnson, S. A. (2003). Debt maturity and the effects of growth opportunities and liquidity risk on leverage. Review of Financial Studies, 16, 209-236. Retrieved from: http://www.jstor.org/ stable/ 1262730

Kayo, E., \& Famá, R. (1997). Teoria de agência e crescimento: evidências empíricas dos efeitos positivos e negativos do endividamento. Caderno de Pesquisas em Administração, 2, 1-8. Retrieved from: http://www.regeusp.com.br/arquivos/c5art1.pdf

Kinnunen, K. (2006). Investment incentives: regulation of the Finnish electricity distribution. Energy Policy, 34(7), 853-862. doi: 10.1016/j. enpol.2004.08.034

La Rocca, M.; La Rocca, T.; Cariola, A. (2011). Capital structure decisions during a firm's life cycle. Small Business Economics, 37(1), 107-130. doi: 10.1007/s11187-009-9229-z 
Lang, L., Ofek, E., \& Stulz, R. M. (1996). Leverage, investment, and firm growth. Journal of Financial Economics, 40, 3-30.

Lassila, J., Viljainen, S., Tahvanainen, K., \& Partanen, J. (2007). New investment strategies in the modern electricity distribution. Business - Reliability in the Long-Term Planning. Power Engineering Society General Meeting, IEEE, 1-8. doi: 10.1109/PES.2007.386105

Luca, J., \& Rambalducci, M. J. G. (2003). Estrutura de capital e o processo de alavancagem financeira: uma discussão sobre a relação entre níveis de endividamento e lucratividade. Terra e cultura, Londrina, ano XIX(37), 147-156.

Margolis, R. M., \& Kammenb, D. M. (1999). Evidence of under-investment in energy R\&D in the United States and the impact of Federal policy. Energy Policy, 27(10), 575-584. doi: 10.1016/ S0301-4215(99)00053-1

McConnell, J. J., \& Servaes, H. (1995). Equity ownership and the two faces of debt. Journal of Financial Economics, 39(1), 131-157. doi: 10.1016/0304-405X(95)00824-X

Milstein, I., \& Tishler, A. (2012). The inevitability of capacity underinvestment in competitive electricity markets. Energy Economics, 34(1), 62-77.

Montoya, M. A., Pasqual, C. A., Lopes, R. L., \& Guilhoto, J. J. M. (2013). As relaçôes intersetoriais do setor energético no crescimento da economia brasileira: uma abordagem insumoproduto. Núcleo de Economia Regional e Urbana da Universidade de São Paulo. Retrieved from: http://www.usp.br/nereus/?txtdiscussao=asrelacoes-intersetoriais-do-setor-energeticono-crescimento-da-economia-brasileira-umaabordagem-insumo-produto

Morgado, A., \& Pintado, J. (2003). The underinvestment and overinvestment hypotheses: An analysis using panel data. European Financial
Management, 9, 163-177. doi: 10.1111/1468036X.00214

Mota, A. F., Coelho, A. C. D., \& Holanda, A. P. (2014). Opção por endividamento na estrutura de capital: evidências em firmas brasileiras. Contextus - Revista Contemporânea de Economia e Gestão, 12(1), 138-165. Retrieved from: http:// www.spell.org.br/documentos/ver/29933/opcaopor-endividamento-na-estrutura-de-capital-evidencias-em-firmas-brasileiras

Myers, S. C. (1977). Determinants of corporate borrowring. Journal of Financial Economics, Amsterdam, 5(2), 147-175. https://doi. org/10.1016/0304-405X(77)90015-0

Myers, S. C. (1984). The capital structure puzzle. The Journal of Finance, Chicago, 39(3), 575-592. doi: 10.1111/j.1540-6261.1984.tb03646.x

Nakamura, W. T., Jucá, M. N., \& Bastos, D. D. (2011). Estrutura de maturidade das dívidas das empresas brasileiras: um estudo empírico. Revista de Administraçâo Contemporânea (2), 228-248. doi: 10.1590/S1415-65552011000200005

Occhino, F., \& Pescatori, A. (2014). Leverage, investment, and optimal monetary policy. The BE Journal of Macroeconomics, 14(1). doi: 10.1515/ bejm-2013-0113

O’Mahony, M., \& Vecchi, M. (2009). R\&D, knowledge spillovers and company productivity performance. Research Policy, 38(1), 35-44. doi:10.1016/j.respol.2008.09.003

Parks, R. W. (1967). Efficient estimation of a system of regression equations when disturbances are both serially and contemporaneously correlated. Journal of the American Statistical Association, 62(318), 500-509. doi: 10.2307/2283977

Perobelli, F. F. C., \& Famá, R. (2002). Determinantes da estrutura de capital: aplicação a empresas de capital aberto brasileiras. Revista de Administração da Universidade de São Paulo, 
São Paulo, 37(3), 33-46. Retrieved from: http://www.spell.org.br/documentos/ver/16659/ determinantes-da-estrutura-de-capital--aplicacaoa-empresas-de-capital-aberto-brasileiras/i/pt-br

Rajan, R., \& Zingales, L. (1995). What do we know about optimal capital structure? Some evidence from international data. The Journal of Finance, Chicago, 50(5), 1421-1460. doi: 10.1111/j.1540-6261.1995.tb05184.x

Ribeiro, F. S. (2009). Determinantes da composição do endividamento das empresas brasileiras: a consideração da maturidade e da fonte de financiamento. Master's Thesis in Applied Economics. Universidade Federal de Juiz de Fora, Juiz de Fora, 83f. Retrieved from: http:// repositorio.uff.br:8080/xmlui/handle/uff/3956

Schroeder, J. T., Schroeder, I., Costa, R. P., \& Shinoda, C. (2005). O custo de capital como taxa mínima de atratividade na avaliação de projetos de investimento. Revista Gestão Industrial, 1(2), 3342. doi: 10.3895/S1808-04482005000200003

Stohs, M. H., \& Mauer, D. C. (1996). Determinants of corporate debt maturity structure. The Journal of Business, 69(3), 279-312. Retrieved from: https://www.jstor.org/stable/ pdf/2353370.pdf?refreqid=excelsior\%3A4fb411 a107460180c2ff96fb1394e0dc

Stulz, R. M. (1990). Managerial discretion and optimal financing policies. Journal of Financial Economics, 26(1), 3-27. doi: 10.1016/0304-405X(90)90011-N

Tolmasquim, M. T. (2012). Perspectivas e planejamento do setor energético no Brasil. Estudos Avançados, 26(74), 247-260. doi: 10.1590/S0103-40142012000100017 
Authors:

1. Aline Kuroda, Federal University of São Carlos, São Carlos - Brazil, E-mail: alinekuroda@gmail.com ORCID

(iD) 0000-0002-3849-6393

2. Herick Fernando Moralles, Federal University of São Carlos, São Carlos - Brazil,

E-mail: herickmoralles@dep.ufscar.br

ORCID

(iD) 0000-0002-5521-9443

3. Andrei Aparecido de Albuquerque, Federal University of São Carlos, São Carlos - Brazil, E-mail: andrei@dep.ufscar.br

ORCID

(iD) 0000-0002-2819-9993

\section{Contribution of each author}

\begin{tabular}{lccc}
\hline Contribution & [Aline] & [Herick] & [Andrei] \\
\hline 1. Definition of research problem & $\sqrt{ }$ & & $\sqrt{ }$ \\
2. Development of hypotheses or research questions (empirical studies ) & $\sqrt{ }$ & $\sqrt{ }$ \\
3. Development of theoretical propositions (theoretical Work) & $\sqrt{ }$ & $\sqrt{ }$ \\
4. Theoretical foundation/ Literature review & $\sqrt{ }$ & & $\sqrt{ }$ \\
5. Definition of methodological procedures & & $\sqrt{ }$ \\
6. Data collection & & & \\
7. Statistical analysis & & $\sqrt{ }$ \\
8. Analysis and interpretation of data & & $\sqrt{ }$ \\
9. Critical revision of the manuscript & $\sqrt{ }$ & $\sqrt{ }$ \\
10. Manuscript Writing & & $\sqrt{ }$ & $\sqrt{ }$ \\
11. Other (please specify which) & & & $\sqrt{ }$ \\
\hline
\end{tabular}

